\title{
PENAMBAHAN RIMPANG KUNYIT (CURCUMA DOMESTICA VAL), RIMPANG TEMULAWAK (CURCUMA XANTHORRIZA ROXB) DAN RIMPANG TEMU PUTIH (CURCUMA ZEDOARIA ROSC) DALAM RANSUM KOMERSIAL TERHADAP PERFORMANS BURUNG PUYUH (Coturnix-coturnix japonica)
}

\author{
Patri Seila Kaselung*, M. E. K Montong**, C. L. K. Sarayar** dan J. L. P. \\ Saerang**
}

Fakultas Peternakan Universitas Sam Ratulangi, Manado 95115

Kata Kunci : Burung Puyuh, Tepung

ABSTRAK

Penelitian ini bertujuan untuk mengetahui sejauh mana efektifitas penambahan tepung kunyit (Curcuma domestica val), Temulawak (Curcuma xhantorriza roxb) dan Temu Putih (Curcuma zedoria rosc) dalam ransum komersial terhadap performans burung puyuh. Materi yang digunakan adalah burung puyuh betina umur 6 minggu sebanyak 120 ekor. Rancangan yang digunakan adalah rancangan acak lengkap dengan 4 perlakuan 5 ulangan. Perlakuan yang diterapkan sebagai berikut : $\mathrm{R}_{0}=$ ransum dasar tanpa kunyit, temulawak, dan temu putih, $\mathrm{R}_{1}=$ ransum dasar $+2 \%$ tepung rimpang kunyit, $R_{2}=$ ransum dasar $+2 \%$ tepung rimpang temulawak, $\mathrm{R}_{3}=$ ransum dasar $+2 \%$ tepung rimpang temu putih. Hasil penelitian menunjukan bahwa penambahan tepung rimpang kunyit, tepung rimpang temulawak dan tepung rimpang temu putih dalam ransum tidak berbeda nyata $(\mathrm{P}>0,05)$ terhadap performans (konsumsi ransum, produksi telur dan konversi ransum). Disimpulkan penambahan tepung rimpang kunyit, tepung rimpang temulawak dan tepung rimpang temu putih sebanyak 2\% dalam ransum komersial belum dapat meningkatkan konsumsi ransum, produksi telur dan menekan konversi ransum.

\footnotetext{
*Alumni Fakultas Peternakan Unsrat **Jurusan Produksi Ternak
} Rimpang Kunyit, Temulawak, Temu putih

\begin{abstract}
ADDITION TURMERIC, GINGER RHIZOME AND WHITE RHIZOME OF COMMERCIAL RATION ON QUAILS' PERFORMANCES. This study aims to determie the effectiveness of the addition of Turmeric powder (Curcuma domestica Val), Javanese ginger powder (Curcuma xanthorriza Roxb) and White turmeric powder (Curcuma zedoaria Rosc) in a commercial ration towards

the performance of quail. The material used were 120 female quails 6 weeks of age. We used the Completely Randomized Design with 4 treatments and 5 replications. The treatments were applied as follows : $\mathrm{R}_{0}=$ basic ration without turmeric, Javanese ginger, and white turmeric powder, $\mathrm{R}_{1}=$ base $+2 \%$ ration turmeric powder, $\mathrm{R}_{2}=$ base $+2 \%$ ration Javanese ginger powder, $\mathrm{R}_{3}=$ base $+2 \%$ ration of Javanese ginger and white turmeric powder. The results showed that the addition of turmeric powder, Javanese ginger powder and white turmeric powder in the ration was not significantly different $(\mathrm{P}>0.05)$ on the performance of quails (feed consumption, egg production and feed conversion). We conclude that the addition of turmeric powder, Javanese ginger powder, and white turmeric powder as much as $2 \%$ in commercial rations didn't raise the feed
\end{abstract}


consumption, egg production, and surpresses the feed conversion.

Keywords : Quail, Turmeric, Javanese Ginger, White Turmeric

\section{PENDAHULUAN}

Untuk

menghasilkan

produktivitas yang tinggi dari burung puyuh maka salah satu hal yang harus diperhatikan adalah kualitas ransum. Rimpang kunyit (Curcuma domestica Val ), rimpang temulawak (Curcuma xanthorriza Roxb), dan rimpang temu putih (Curcuma zedoaria Rosc) merupakan tanaman herbal yang dapat digunakan sebagai bahan pakan tambahan dalam ransum ternak burung puyuh. Kunyit merupakan tanaman herbal telah lama dikenal masyarakat yang memiliki kandungan minyak atsiri yang dapat menekan bakteri dan kandungan kurkuminnya dapat menjaga daya tahan tubuh. Temulawak memiliki kandungan minyak atsiri, kurkumin, dan xanthorizol yang mampu menekan jamur, meningkatkan nafsu makan dan dapat meningkatkan performans ternak. Temu putih (Curcuma zedoaria Rosc) mengandung minyak atsiri dan komponen kurkuminoid dan fungsinya dapat membantu pencernaan dan merangsang sistim saraf dan juga berkhasiat sebagai stomakhik atau memperkuat pencenaan dan menambah nafsu makan.

Hasil penelitian Penelitian penggunaan Rimpang kunyit, temulawak dan temu putih sebagai bahan pakan tambahan dalam ransum burung puyuh sampai saat ini belum banyak dilakukan. Namun beberapa penelitian yang dilakukan untuk ayam pedaging telah banyak dilakukan antara lain hasil penelitian Dien $d k k$ (2012) bahwa penggunaan herbal kunyit dan temulawak difermentasi dengan $\mathrm{EM}_{4}$ dalam air minum ternyata dapat meningkatkan perfomans ayam broiler, ditinjau dari pertambahan berat badan dan konversi ransum.

$$
\text { Berdasarkan pemikiran }
$$
tersebut, maka telah dilakukan penelitian untuk mengetahui seberapa besar pengaruh penambahan tepung rimpang kunyit, temulawak dan temu putih dalam ransum komersial terhadap performans burung puyuh.

\section{MATERI DAN METODE PENELITIAN}


Sebanyak 120 ekor burung puyuh berumur 6 minggu digunakan dalam penelitian ini yang terbagi menjadi 4 perlakuan 5 ulangan. Masing-masing ulangan terdiri dari 6 ekor. Perlakuan yang diberikan $\mathrm{R}_{0}$ : Ransum dasar tanpa kunyit, temulawak, dan temu putih, $\mathrm{R}_{1}$ : ransum dasar $+2 \%$ tepung rimpang kunyit, $\mathrm{R}_{2}$ : ransum dasar $+2 \%$ tepung rimpang temulawak dan $\mathrm{R}_{3}$ : ransum dasar $+2 \%$ tepung rimpang temu putih. Rancangan yang digunakan pada penelitian ini adalah Rancangan Acak Lengkap (RAL). Penelitian ini dilakukan dikandang percobaan Jurusan ilmu Produksi Fakultas Peternakan Universitas Sam Ratulangi Manado.

\section{Variabel yang diamati.}

- Konsumsi ransum dihitung menurut Rasyaf (2006), ransum yang diberikan dikurangi ransum sisa dibagi jumlah ternak.

- Produksi telur dihitung menurut Sudradjat (2002), jumlah produksi telur per butir dibagi jumlah ternak saat penelitian dikali $100 \%$.
- Konversi Ransum merupakan rasio pakan yang dikonsumsi dalam jangka waktu tertentu dibandingkan dengan berat telur yang dihasilkan dalam waktu tertentu (Handarini dkk., 2008):

\section{Analisa Data}

Data dianalisis secara statistik menggunakan analisis ragam dengan Rancangan Acak Lengkap (RAL) (Steel dan Torrie, 1994).

\section{HASIL DAN PEMBAHASAN}

\section{Pengaruh Perlakuan Terhadap Konsumsi Ransum}

Data hasil perhitungan rataan konsumsi ransum dari masingmasing perlakuan yang diberikan selama penelitian tercantum pada Tabel 1. Rataan konsumsi ransum burung puyuh selama penelitian berkisar antara 24,76 sampai 25,36 (g/ekor/hari). Kisaran ini masih berada dalam standar kebutuhan sesuai yang direkomendasikan oleh Djanah dan Sulistyani (1985) menyatakan bahwa konsumsi ransum burung puyuh umur 6 
minggu sekitar 15 - 25 gram per ekor per hari.

Hasil analisis sidik ragam menunjukan bahwa perlakuan memberikan pengaruh yang tidak nyata $(\mathrm{P}>0,05)$ terhadap konsumsi ransum. Hal ini menunjukan bahwa masing-masing perlakuan memberikan respons yang sama. Pada Tabel 4 terlihat ada kecenderungan penurunan konsumsi ransum, diduga ransum yang menggunakan tepung rimpang kunyit, tepung rimpang temulawak, dan tepung rimpang temu putih mengandung minyak atsiri yang mempunyai aroma dan rasa yang tajam. Menurut Afifah dan Lantera (2003) menyatakan bahwa penggunaan temulawak harus dibatasi pemberiannya karena adanya kandungan minyak atsiri pada temulawak mempunyai bau dan rasa yang tajam. Hal ini sependapat dengan Lumbantoruan (2005) yang menggunakan tepung temulawak dalam ransum pada ayam broiler, memberikan pengaruh terhadap palatabilitas yaitu menurunkan palatabilitas. Hal ini disebabkan tepung temulawak mengandung minyak atsiri dan zat warna curcumin yang mengakibatkan palatabilitas menurun karena bau dan rasa yang tajam dan warna yang lebih pekat. Selanjutnya Widodo (2002) menyatakan bahwa penggunaan temulawak sebesar $2 \%$ dalam ransum merupakan dosis terbaik karena menunjukan pertambahan berat badan yang diikuti dengan tingkat konsumsi ransum yang rendah.

Tabel 1. Rataan konsumsi ransum per ekor dari masing-masing perlakuan (gram)

\begin{tabular}{ccllc}
\hline \multirow{2}{*}{ ULANGAN } & \multicolumn{5}{c}{$\begin{array}{c}\text { PERLAKUAN } \\
\text { (gram) }\end{array}$} \\
\cline { 2 - 5 } & $\mathrm{R}_{0}$ & $\mathrm{R}_{1}$ & $\mathrm{R}_{2}$ & $\mathrm{R}_{3}$ \\
\hline 1 & 24.97 & 25.39 & 24.92 & 25.15 \\
2 & 25.98 & 25.02 & 25.00 & 24.92 \\
3 & 25.23 & 25.04 & 24.19 & 25.03 \\
4 & 25.31 & 24.51 & 24.74 & 25.50 \\
5 & 25.30 & 24.85 & 24.96 & 23.88 \\
\hline RATAAN & 25.36 & 24.96 & 24.76 & 24.90 \\
\hline
\end{tabular}




\section{Pengaruh Ransum Perlakuan Terhadap Produksi Telur}

Hasil pengamatan rataan produksi telur dari masing-masing perlakuan yang

diberikan selama penelitian tercantum pada Tabel 2. Rataan produksi telur burung puyuh umur 6 minggu berkisar antara $60,75 \%$ sampai $69,07 \%$. Hasil penelitian ini tidak jauh berbeda dengan hasil penelitian yang dilakukan oleh Kusumowati (1992); Tiwari dan Panda (1987) dimana produksi telur burung puyuh umur 5-6 minggu berkisar antara 54,75\% - 67\%. Selanjutnya Sugiharto (2005) mengatakan bahwa puncak produksi telur pada burung puyuh mencapai 98,5\% pada umur 4-5 bulan.

Hasil analisis sidik ragam menunjukan bahwa perlakuan memberikan pengaruh yang tidak nyata $(\mathrm{P}>0,05)$ terhadap produksi telur. Hal ini menunjukkan bahwa setiap perlakuan

yang diberikan memberikan pengaruh yang sama terhadap produksi telur burung puyuh. Walaupun secara statistik tidak berbeda nyata namun penambahan tepung rimpang kunyit 2\% menghasilkan produksi yang lebih tinggi diikuti dengan perlakuan yang menggunakan tepung rimpang temulawak dan tepung rimpang temu putih. Meningkatnya produksi telur pada perlakuan $\mathrm{R}_{1}$ diduga antara lain karena kunyit mengandung zat aktif kurkumin yang dapat berfungsi sebagai antibakteri dan kandungan zat fitokimia yang biasa disebut demetoksikurkumin, yang dapat menigkatkan sekresi empedu, memperbaiki fungsi hati, memperbaiki tampilan limfosit darah dan menjaga daya tahan tubuh. Dengan kondisi kesehatan yang optimal sehingga pada perlakuan $R_{1}$ dapat menghasilkan produksi telur yang baik. Sedangkan perlakuan $R_{2}$ dan $\mathrm{R}_{3}$ (Tabel 2) ada kecenderungan penurunan produksi telur pada burung puyuh, diduga $\mathrm{R}_{1}$ mengandung kurkumin lebih tinggi dibandingkan perlakuan $\mathrm{R}_{2}$ dan $\mathrm{R}_{3}$. Hasil analisa Sinurat et al (2009) kandungan kurkumin pada kunyit $9,61 \%$ dan temulawak 2,00 \% sedangkan temu putih kandungan kurkuminnya tidak terdeteksi. 
Tabel 2. Rataan produksi telur per ekor dari masing-masing perlakuan (\%)

\begin{tabular}{ccccr}
\hline \multirow{2}{*}{ ULANGAN } & \multicolumn{4}{c}{$\begin{array}{c}\text { PERLAKUAN } \\
(\%)\end{array}$} \\
\cline { 2 - 5 } & $\mathrm{R}_{0}$ & $\mathrm{R}_{1}$ & $\mathrm{R}_{2}$ & $\mathrm{R}_{3}$ \\
\hline 1 & 65.79 & 73.74 & 59.58 & 67.00 \\
2 & 70.55 & 60.84 & 58.95 & 58.90 \\
3 & 61.17 & 65.83 & 56.33 & 59.00 \\
4 & 70.38 & 66.66 & 68.68 & 58.45 \\
5 & 77.33 & 78.28 & 65.29 & 60.38 \\
\hline RATAAN & 69.04 & 69.07 & 61.77 & 60.75 \\
\hline
\end{tabular}

menunjukkan bahwa setiap

Pengaruh Perlakuan Terhadap Konversi Ransum

Rataan konversi ransum berkisar antara 2,32 sampai 2,48. Menurut penelitian Kartasudjana dan Nayoan (1997) konversi pakan burung puyuh yang baik berkisar antara 2,70 sampai 2,80. Hal ini didukung oleh Campbell (1984) menyatakan angka konversi pakan menunjukan tingkat penggunaan pakan dimana jika angka konversi semakin kecil maka penggunaan pakan semakin efisien dan sebaliknya jika angka konversi besar maka penggunaan ransum tidak efisien.

Hasil analisis sidik ragam menunjukan bahwa pemberian ransum pada penelitian memberikan pengaruh yang tidak nyata $(\mathrm{P}>0,05)$ terhadap konversi. Hal ini perlakuan mempunyai kemampuan yang sama dalam menggubah ransum untuk menjadi produk. North (1984), menyatakan bahwa konsumsi ransum dan berat telur merupakan dua faktor yang menentukan tinggi rendahnya konversi ransum, jika dua faktor tersebut dalam keadaan seimbang maka akan diperoleh konversi yang lebih baik dimana besarnya angka konversi ransum tergantung pada banyaknya ransum yang dikonsumsi dibagi dengan berat telur yang dihasilkan. Dalam pengertian konversi adalah jumlah ransum yang dihabiskan untuk tiap satuan produksi (penambahan bobot badan, berat telur dan produksi lainnya) . Semakin banyak ransum yang dikonsumsi untuk menghasilkan satu satuan produksi maka makin buruklah pakan tersebut. Baik 
buruknya konversi ransum dipengaruhi oleh berbagai faktor diantaranya mutu ransum, kesehatan ternak dan tata cara pemberian ransum (Tillman et al, 1991).

Dari hasil penelitian diperoleh nilai konversi ransum terendah terdapat pada perlakuan $R_{2}$ dibandingkan dengan perlakuan lainnya. Hal ini berarti nilai konversi ransum perlakuan $\mathrm{R}_{2}$ lebih baik dari perlakuan lainnya karena, berat telur (Lampiran 4) yang dihasilkan lebih tinggi dibandingkan perlakuan $\mathrm{R}_{0}$, $\mathrm{R}_{1}, \mathrm{R}_{3}$. Hal ini menunjukan bahwa penggunaan feed additive temulawak mampu memperbaiki daya cerna dan konsumsi ransum sehingga menghasilkan berat telur yang lebih tinggi. Anggorodi (1985) menyatakan bahwa faktor-faktor yang mempengaruhi konversi ransum adalah jumlah konsumsi ransum, daya cerna dan penggunaan zat-zat makanan.

Tabel 3. Rataan konversi ransum per ekor dari masing-masing perlakuan

\begin{tabular}{ccccc}
\hline \multirow{2}{*}{ ULANGAN } & \multicolumn{4}{c}{ PERLAKUAN } \\
\cline { 2 - 5 } & $\mathrm{R}_{0}$ & $\mathrm{R}_{1}$ & $\mathrm{R}_{2}$ & $\mathrm{R}_{3}$ \\
\hline 1 & 2.37 & 2.39 & 2.26 & 2.52 \\
2 & 2.37 & 2.35 & 2.37 & 2.50 \\
3 & 2.38 & 2.32 & 2.31 & 2.53 \\
4 & 2.61 & 2.54 & 2.15 & 2.48 \\
5 & 2.32 & 2.66 & 2.52 & 2.36 \\
\hline RATAAN & 2.41 & 2.45 & 2.32 & 2.48 \\
\hline
\end{tabular}




\begin{abstract}
KESIMPULAN
Hasil penelitian ini menunjukan bahwa dengan penambahan tepung rimpang kunyit, tepung rimpang temulawak dan tepung rimpang temu putih sebanyak $2 \%$ dalam ransum komersial belum dapat meningkatkan konsumsi ransum, produksi telur dan menekan konversi ransum.
\end{abstract}

\section{DAFTAR PUSTAKA}

Afifah, E. dan Tim Lentera, 2003. Khasiat dan Manfaat Temulawak. PT Gramedia Pustaka, Jakarta.

Anggorodi, H.R., 1985. Nutrisi Aneka Ternak Unggas. Gramedia Pustaka Utama, Jakarta.

Anggrodi, H.R., 1995. Nutrisi Aneka Ternak Unggas.

Gramedia Pustaka

Utama, Jakarta.

Bintang, I.A.K dan A.G. Nataamijaya. 2005. Pengaruh
Penambahan Tepung Kunyit

Terhadap Performans Broiler. Prosiding Seminar Nasional Teknologi Peternakan dan Veteriner. Bogor, 12-13 September 2005. Puslitbang Peternakan. Bogor. Hlm773777.

Campbell, W., 1984. Principles of Fermentation

Technology. Peragaman

Press, New York.

Dien, P. A., Montong, M.E.R., Adiani S., Tangkere, E.S. 2012. Efektivitas Penggunaan Herbal Kunyit (Curcuma domestica Val) dan Temulawak (Curcuma xanthorriza Roxb) Yang Difermentasi Dengan $\mathrm{EM}_{4}$ Dalam Air Minum Ayam Broiler. Skripsi. Fakultas Peternakan Universitas Sam Ratulangi. Manado.

Djanah, D., dan Sulistyani. 1985. Beternak Puyuh. CV Simplek. Jakarta.

Handarini R. Saleh E. \& Togatorop B., 2008. Produksi Burung 
Puyuh Yang Diberi Ransum

Dengan Penambahan Tepung

Umbut Sawit Fermentasi.

Agribisnis Petrnakan, Vol. 4.

No. 3. Hal 107.

Kartasudjana R., dan Nayoan M. 1997. Pengaruh limbah ikan cakalang dalam ransum terhadap performans puyuh petelur. J. Pengembangan Peternakan Tropis. UNDIP, Semarang. 22(4) : 12-18.

Kusumowati, E. $\quad$ S. 1992. Penggunaan pengaruh zeolit dalam ransum puyuh (Coturnix coturnix japonica) terhadap produksi dan kualitas telur pada periode produksi umur 13-19 minggu. Skripsi. Fakultas Peternakan Institut Pertanian Bogor, Bogor.

Liang, O.B., Y.Absartom, Y. Widjaya, dan Y. Puspa. 1985. Beberapa aspek isolasi, identifikasi dan penggunaan komponen-komponen

Curcuma xanthoriza Roxb dan Curcuma domestica Val. Proseding Simposium Nasional Temulawak. Lembaga Penelitian
Universitas Padjajaran.

Bandung.

Lumbantoruan T. 2005. Skripsi pemanfaatan tepung temulwak (Curcuma xanthorriza Roxb) dalam ransum dan pengaruhnya terhadap performans ayam broiler umur 0-6 minggu.

North, M.O. 1984. Commercial Chikens Production Manual. $3^{\text {rd }}$ Edition. Penerbit The Avi Publishing Company Inc. Wesport Connection, New York.

Scott , M. L., C. Nesheim and R. J. Young. 1992. Nutrition of The Chicken $3^{\text {rd }}$ Ed. Cornell University. M.L Scott of Ithaca, New York.

Steel, R.G.D and J.H. Torrie, 1994. Prinsip dan Prosedur Statistika Suatu Pendidikan Giometrik. PT. Gramedia Pustaka Utama. Jakarta.

Sinurat. A., Purwadaria. T, Bintang. I.A.K. Ketaren. P.P Bernawie.N. Raharjo. M. Rizal.M. 2009.Pemanfaatan Kunyit dan Tembulawak 
Sebagain Imbuhan Pakan

Untuk Ayam Broiler. JITV

$14(2): 90-96$

Sugiharto, E., 2005. Meningkatkan Keuntungan Berternak

Puyuh. Agromedia Pustaka, Jakarta.

Suprijatna, E., Atmomarsono U., dan Kartasudjana R. 2008. Ilmu Dasar Ternak Unggas. Cetakan 2. Penebar Swadaya. Jakarta.

Tillman, A. D., H. Hartadi, S. Reksohadiprodjo, S.
Prawirokusumo dan S.Lebdosoekojo, 1991. Ilmu Makanan Ternak Dasar. Gadjah Mada University Press. Yogyakarta.

Tiwari, K.S. and B. Panda. 1978. Production and quality characteristics of quail eggs. Indian Journal of Poultry Sci 13 (1): 27-32

Wahyu, J. 1992. Ilmu Nutrisi Ternak Unggas.Gadjah Mada University Press. Yogyakarta 